Original Article

\title{
The role of purslane in modulating diverse effects of high fat diet on biochemical, histological, and molecular parameters of rats' liver
}

\author{
O papel da beldroega na modulação de diversos efeitos da dieta rica em gordura nos \\ parâmetros bioquímicos, histológicos e moleculares do fígado de ratos
}

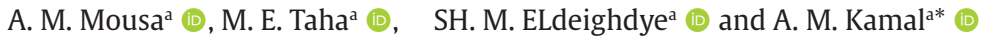 \\ ${ }^{a}$ Egyptian Atomic Energy Authority - EAEA, Nuclear Research Center - NRC, Biological Applications Department, Cairo, Egypt
}

\begin{abstract}
Consuming a high-fat diet causes a harmful accumulation of fat in the liver, which may not reverse even after switching to a healthier diet. Different reports dealt with the role of purslane as an extract against high-fat diet; meanwhile, it was necessary to study the potential role of fresh purslane as a hypolipidemic agent. This study is supposed to investigate further the potential mechanism in the hypolipidemic effect of fresh purslane, by measuring cholesterol 7a-hydroxylase (CYP7A1) and low-density lipoprotein receptor (Ldlr). Rats were divided into two main groups: the first one is the normal control group ( $\mathrm{n}=7$ rats) and the second group ( $\mathrm{n}=28$ rats) received a high fat diet for 28 weeks to induce obesity. Then the high fat diet group was divided into equal four subgroups. As, the positive control group still fed on a high fat diet only. Meanwhile, the other three groups were received high-fat diet supplemented with a different percent of fresh purslane (25, 50 and $75 \%)$ respectively. At the end of the experiment, rats were sacrificed and samples were collected for molecular, biochemical, and histological studies. Current study reported that, supplementation of fresh purslane especially at a concentration of $75 \%$ play an important role against harmful effects of high-fat diet at both cellular and organ level, by increasing CYP7A1 as well as Ldlr mRNA expression. Also, there were an improvement on the tested liver functions, thyroid hormones, and lipid profile. Fresh purslane plays the potential role as a hypolipidemic agent via modulation of both Ldlr and Cyp7A, which will point to use fresh purslane against harmful effects of obesity.
\end{abstract}

Keywords: fresh purslane (Portulaca oleraceae), high-fat diet, lipid profile, liver functions, Ldlr and Cyp7A1.

\begin{abstract}
Resumo
O consumo de uma dieta rica em gordura causa um acúmulo prejudicial de gordura no fígado, que pode não reverter mesmo após a mudança para uma dieta mais saudável. Diferentes relatórios trataram do papel da beldroega como um extrato contra uma dieta rica em gordura; entretanto, foi necessário estudar o papel potencial da beldroega fresca como agente hipolipemiante. Este estudo pretende investigar mais profundamente o mecanismo potencial no efeito hipolipidêmico da beldroega fresca, medindo o colesterol 7a-hidroxilase (CYP7A1) e o receptor de lipoproteína de baixa densidade (Ldlr). Os ratos foram divididos em dois grupos principais: o primeiro é o grupo controle normal ( $n=7$ ratos) e o segundo grupo ( $n=28$ ratos) recebeu dieta rica em gorduras por 28 semanas para induzir a obesidade. Em seguida, o grupo de dieta rica em gordura foi dividido em quatro subgrupos iguais. Como, o grupo de controle positivo ainda se alimentava apenas com dieta rica em gordura. Enquanto isso, os outros três grupos receberam dieta rica em gordura suplementada com diferentes porcentagens de beldroegas frescas (25\%, 50\% e 75\%), respectivamente. Ao final do experimento, os ratos foram sacrificados e amostras coletadas para estudos moleculares, bioquímica e histológicos. O estudo atual relatou que a suplementação de beldroegas frescas, especialmente a uma concentração de 75\%, desempenha papel importante contra os efeitos prejudiciais da dieta rica em gordura em nível celular e orgânico, aumentando a expressão de CYP7A1 e Ldlr mRNA. Além disso, houve melhora nas funções hepáticas testadas, nos hormônios tireoidianos e no perfil lipídico. Beldroegas frescas desempenham papel potencial como agente hipolipemiante por meio da modulação de Ldlr e Cyp7A, o que apontará para o uso de beldroegas frescas contra os efeitos nocivos da obesidade.
\end{abstract}

Palavras-chave: beldroegas frescas (Portulaca oleraceae), dieta rica em gordura, perfil lipídico, funções hepáticas, Ldlr e Cyp7A1.

*e-mail: amaalkamal5@gmail.com

Received: February 15, 2021 - Accepted: April 23, 2021 


\section{Introduction}

The current lifestyle with high-fat diet and less physical activity notably contribute to obesity, which will increase risks of different diseases (Shanker and Debnath, 2016). According to data from the World Health Organization (WHO), one billion adults that are approximately overweight currently exist in the world, of which three hundred million are obese. These numbers led to the finding that obesity appears as a major global epidemic, affecting countries in all stages of development (Pereira et al., 2010). One of the most organs affected by high-fat diet is the liver (Rohit et al., 2010). As, the most frequent causes of hepatic disease include infectious agents and obesity-related fatty liver disease-induced liver injury (Engiz et al., 2009). The accumulation of fat in the liver tissue was proposed to be the first hit which then increased the sensitivity of the liver to the second hits, mainly from increased oxidative stress and the release of pro-inflammatory cytokines, which cause inflammation and tissue damage (Anstee and Goldin, 2006). The most frequent causes of hepatic disease include infectious agents and obesity-related fatty liver disease- induced liver injury (Sharma and Patni, 2012). There are more than a hundred well-known liver diseases with diversified etiopathology. The treatment options for common liver diseases are limited due to the lack of hepatoprotective drugs in allopathic medicine. Moreover, therapies developed along the principle of western medicine are often limited in efficacy, carry the risk of adverse effects, and are often too costly, especially for the habitants of the developing world. The effectiveness of treatments such as those using corticosteroids and interferon is inconsistent, carried the risk of adverse events, and is often too costly (Girish and Pradhan, 2012).

A large number of medicinal plants and their constituents have been known to possess beneficial therapeutic potential. Portulaca oleracea $L$. is one of the most used medicinal plants and a member of the family Portulacaceae. It contains a high antioxidant property (Dkhil et al., 2011), which is mainly attributed to the rich source of omega-3, polyunsaturated fatty acids (Oliveira et al., 2009); flavonoid compounds; particularly kaempferol, apigenin, myricetin, quercetin, luteolin, carotene and alkaloids (Xu et al., 2006; Zhou et al., 2015). Portulaca oleraceae, are also, a rich source of other antioxidants such as A, B1, B2, C, E, beta-carotene, and other essential amino acids. This plant is also a rich source of minerals such as calcium, iron, phosphorus and copper. Its medicinal value is evident from its use for the treatment of diabetic wounds (Eldeighdye et al., 2016) burns, headaches, and diseases related to the intestine, liver, stomach, cough, shortness of breath, and arthritis. Its use as a purgative, cardiac tonic, emollient, muscle relaxant, and anti-inflammatory and diuretic treatment makes it important in herbal medicine. Purslane has also been used in the treatment of osteoporosis and psoriasis. Recent research demonstrates that purslane has better nutritional quality than the major cultivated vegetables (Uddin et al., 2014). On the other hand, traditional medicinal systems of China, India, Europe, and Middle
Eastern countries have used Portulaca oleracea to treat various human diseases (Bosi et al., 2009). In addition, several studies mainly indicated the hypolipidemic role of Purslane at the orange activity level (Shanker and Debnath, 2018). Meanwhile, we hypothesized that fresh purslane has a hypolipidemic effect via induction of both CYP7A1 and LDLR genes expression.

\section{Materials and Methods}

\subsection{Animals}

Thirty- five (35) male albino rats of age 11 weeks weighing between 120-130 gm., were used for this study. The experimental protocol was approved by the Research Ethics Committee, serial number 6A/21 of the National Center for Radiation Research and Technology, Egyptian Atomic Energy Authority, Cairo, Egypt.

The animals were obtained from the animal house in Egyptian Atomic Energy Authority, Nuclear Research Center, Biological Application Department.

Animals were allowed for acclimatization 2 weeks under standard laboratory conditions, i.e. room temperature of $28 \pm 2{ }^{\circ} \mathrm{C}$ and a $12: 12 \mathrm{~h}$ dark/light cycle, and housed in specific cages as 7 rats per cage, with standard diet and tap water add libitum.

\subsection{Chemicals}

All chemicals were of analytical grade and were obtained from commercial sources includes (Sigma, Bio-diagnostic, and spine- react).

\subsection{High fat diet}

According to Woods et al. (2003), 20 gm butter was added to $80 \mathrm{gm}$ control diet for 28 weeks.

\subsection{Plant material}

Fresh specimens of purslane were collected from the farm of Zaggazig - Egypt.

\subsection{Feeding of fresh purslane}

Fresh purslane was added to the previous mixture of the high fat diet with 3 different percent as (25, 50 and 75\%).

\subsection{Methods}

\subsubsection{Experimental groups}

After the acclimation period ( 2 weeks) rats were divided to main groups, control group "G1" feed on normal diet. High-fat diet group "G2”, feeds on HFD for 28 weeks. Then "G2" was divided into 4 subgroups "G2, G3, G4, and G5" (see next subsection):

Group 1: Negative control group "G1", normal rats;

Group 2: Positive control (high fat diet group) "G2”, rats still feed on high-fat diet (HFD) only;

Group 3: Rats were daily administered with $25 \%$ fresh purslane in (HFD); 
Group 4: Rats were daily administered with $50 \%$ fresh purslane in (HFD);

Group 5: Rats were daily administered with $75 \%$ fresh purslane in (HFD).

\subsubsection{Samples collection}

\subsubsection{Blood and tissue sampling}

At the end of the experiment ( 8 weeks), fasted rats ( $12 \mathrm{~h}$ ) were anesthetized and sacrificed. Then blood samples were collected into fresh vials without anticoagulant, the liver and total adipose tissue weighed immediately, blood samples were centrifuged at $3000 \mathrm{rpm}$ for $10 \mathrm{~min}$. and serum was stored in $\left(-20^{\circ} \mathrm{C}\right)$ until using in clinical analysis.

\subsubsection{Molecular studies}

\subsubsection{RNA extraction protocol}

Total RNA was isolated from frozen liver tissue, which purified through mRNA isolation Kit, Roche (www.rocheapplied-sceince.com) according to manufacturer protocol.

\subsubsection{DNA construction and gene detection}

Preparation of C-DNA from total extracted RNA of five tissue samples, was carried out via Verso 1-Step RT-PCR Reddy Mix Kit (Thermo Scientific, AB-1454/LD/A) according to manufacturer protocol with the addition of two specific primers (primer listed in Table 1).

\subsubsection{PCR amplification}

Specific DNA was amplified through Gene-Amp Polymerase Chain Reaction (Creacon, Thermo cycler, Holand) system cycler. PCR for amplified genomic DNA was carried out.

The reaction consists of 30 cycles of $95{ }^{\circ} \mathrm{C}$ for $15 \mathrm{~s}$, $60{ }^{\circ} \mathrm{C}$ for $60 \mathrm{~s}$, and $72{ }^{\circ} \mathrm{C}$ for $30 \mathrm{~s}$; for Cyp7a1 and $L d l r$, PCR amplification employed $\beta$-actin as an internal control.

\subsubsection{Agarose gel electrophoresis and detection of the amplification products}

$1.5 \%$ agarose solution was prepared by adding $0.75 \mathrm{~g}$ agarose to $50 \mathrm{~mL}$ of $1 \mathrm{x}$ TBE electrophoresis buffer in $50 \mathrm{~mL}$ flask. Heating in a microwave oven then dissolved the agarose. The agarose was cooled in a $50{ }^{\circ} \mathrm{C}$. A comb was inserted in the electrophoresis bed and the agarose was poured into it.

Great care should be taken during the pouring of the agarose to avoid bubbles formation. The gel solidified within 15 min and became cloudy, the electrophoresis apparatus was filled with the electrophoresis buffer and the comb was removed creating 6 or 10 wells for the sample application. Electrodes were connected to the power supply and the latter was turned on. It was adjusted at 80 Volts for $100 \mathrm{~min}$. The gel was removed from its bed and transferred to the gel staining tray for staining with Ethidium bromide for 30 min followed by 20 min destain in distilled water.

\subsubsection{Data analysis}

Gel documentation system (Geldoc-it, UVP, and England), was applied for data analysis using Total lab analysis software, ww.totallab.com, (Ver.1.0.1).

\subsubsection{Biochemical analysis}

Serum levels of total cholesterol (TC), triglyceride (TG), low-density lipoproteins (LDL), high-density lipoprotein (HDL), alanine transaminase (ALT), aspartate transaminase (AST), alkaline phosphatase (ALP), total protein, and albumin all parameters were evaluated according to manufacturer's instructions of commercially available kits from Bio-diagnostic company, Dokki, Giza, Egypt.

Serum total T3 and T4 were measured using the radioimmunoassay technique according to the method of (Larsen, 1972; Tietz, 1995), respectively.

\subsubsection{Histopathological study}

To evaluate the histopathological changes in the tissue of the liver for all groups. The sacrificed rats were dissected; liver tissues were removed and preserved in $10 \%$ formalin for fixation of the tissues then embedded in paraffin cubes. Thin sections (4-5 mm) were stained with hematoxylin and eosin (H\&E) solution and examined under light microscope power of (X 100-400) for histopathological examination (Culling, 1983).

\subsubsection{Statical analysis}

Data were statistically evaluated by use of one-way ANOVA, followed by post hoc Duncan's test using version 25 of the SPSS computer software. The values were considered non-significant when $\mathrm{p}<0.05$ (Levesque, 2005).

Table 1. Specific Primer sequence under study.

\begin{tabular}{cc}
\hline Genes & \multicolumn{1}{c}{ Sequences } \\
\hline Cholesterol 7 $\alpha$-hydroxylase (Cyp7a1) & Forward 5'-GCCGTCCAAGAAATCAAGCAGT-3', \\
Low-density lipoprotein- receptor $($ Ldlr $)$ & Reverse 5'-TGTGGGCAGCGAGAACAAAGT-3'; \\
& Forward 5'-ATTTGGAGGATGAGAAGCAG-3', \\
& Reverse 5'-CAGGGCGGGGAGGTGTGAGAA-3'; \\
& Forward 5'-TGGGGCGCCCCAGGCACCAGGGC-3', \\
\hline
\end{tabular}




\section{Results}

\subsection{Molecular study}

We scanned the effect of cholesterol synthesis in the high fat-fed (HFD) after fresh purslane (P. O.) feeding of rats. Data of the present study postulated that, Cyp7a1 mRNA levels have a significant increase in all groups compared to the normal group (G1). After treatment of the high-fat diet group (G2) with different amounts of fresh purslane (F.P.) $25 \%, 50 \%$, and $75 \%$ in G3, G4, and G5 respectively), mRNA levels of Cyp7a1 increased significantly. Whereas, the highest mRNA level of Cyp7a1 was recorded in the G4 group (Figure 1) and (Table 2). In addition, Ldlr mRNA expression was significantly increased in all groups (G2, G3, G4, and G5) compared to the normal group (G1), whereas, the highest mRNA expression of Ldlr level was found in the G5 group (Figure 2, Table 2).

\section{G1 $\quad$ G2 $\quad$ G3 $\quad$ G4 $\quad$ G5}

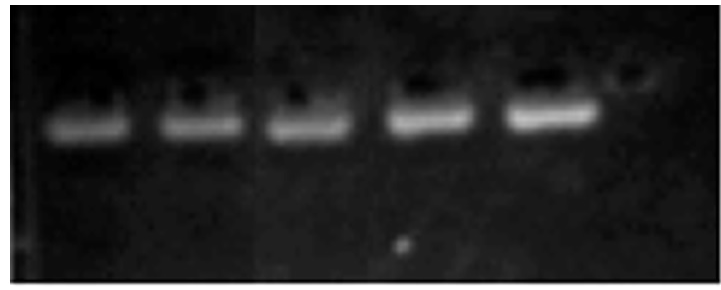

Figure 1. Specific genomic product for Cyp7a1 mRNA expression level for different groups.

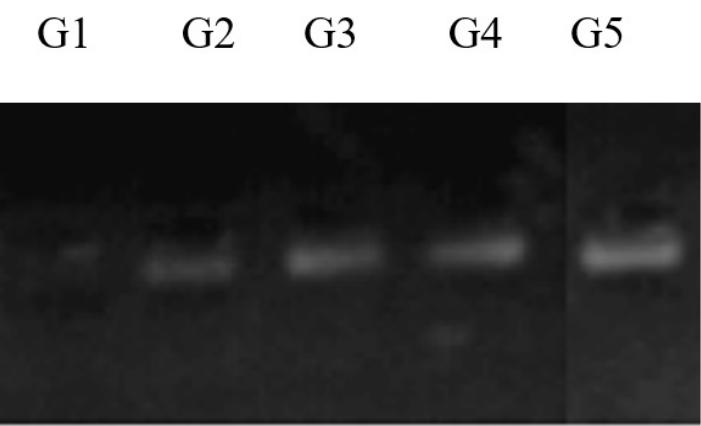

Figure 2. Specific genomic product for Ldlr mRNA expression level for different groups.

Table 2. Cyp7a1 and Ldlr genes mRNA expression levels for different groups.

\begin{tabular}{cccccc}
\hline \multirow{2}{*}{$\begin{array}{c}\text { Genes -mRNA/ } \\
\text { expression level }\end{array}$} & G1 & G2 & G3 & G4 & G5 \\
\cline { 2 - 6 } & 4.26 & 4.93 & 5.67 & 7.91 & 5.86 \\
\hline Cyp7a1 gene & - & 4.42 & 5.95 & 6.72 & 8.07 \\
Ldlr gene & &
\end{tabular}

3.2. Effect of fresh purslane on the liver and adipose tissue weights as well as serum lipid parameters

There was a significant increase in liver weight in high-fat diet (HFD) group compared to the control group. While, administration of fresh purslane in G3, G4, and G5 groups showed a significant decrease in liver weight when compared to (HFD) group. Additionally, there are a significant increase in total adipose tissue weight (HFD) rats compared to the control group. Meanwhile, fed with different percentages (25\%, 50\%, $75 \%$ ) showed a significant decrease in total adipose tissue weight in G3, G4, and G5 groups respectively (Table 3 ).

In lipid profile (total cholesterol $\mathrm{CH}$, triglyceride $\mathrm{TG}$, and low-density lipoprotein LDL), there was a significant increase associated with a decrease in HDL in (HFD) group compared to the control group. On the other hand, administration of fresh purslane $(25 \%, 50 \%$, and $75 \%)$ showed a significant decrease in lipid profile $(\mathrm{CH}, \mathrm{TG}$ and LDL) associated with an increase in HDL compared to (HFD) group (Table 3). Overcome, administration of fresh purslane $75 \%$ showed a highly significant effect comparing to other two concentrations ( $25 \%$ and $50 \%$ ).

\subsection{Effect of fresh purslane on liver functions}

There was a significant increase in liver enzymes (AST, ALT, and ALP) in (HFD) group compared to the control group whereas, the administration of purslane 25, 50, and $75 \%$ showed a significant decrease in (AST, ALT, and ALP) parameters compared to high-fat diet group. Moreover, there was a significant decrease in total protein and albumin in (HFD) group compared to the control group, meanwhile, administration of purslane showed significant improvement in both albumin and total protein compared with (HFD) group as shown in Table 4.

In addition, there was a significant increase in $\mathrm{T}_{3}$ and $\mathrm{T}_{4}$ hormones levels in the high-fat diet group" G2" compared to the normal group, however, the administration of fresh purslane $(25 \%, 50 \%, 75 \%)$ significantly reduced $\mathrm{T}_{3}$ and $\mathrm{T}_{4}$ level near to the normal group, As shown in the Figure 3.

\subsection{Histological changes}

The histological study of the liver confirms both the current molecular and clinical studies, which showed that in the positive control group (HFD - B) there were changes in the photographic of liver tissue that showing, marked portal tract changes, note the dilated and congested hepatoportal blood vessel (arrowhead) and fibrous connective tissue proliferations (Arrow) and (Lesion score +++) compared with negative control group" $G 1$ "(A) which showing healthy hepatic parenchyma, note the normal hepatic cord with normal blood sinusoids. Meanwhile, there were observed changes between positive control group "G2" and Portulaca oleracea groups "G3"," G4" and "G5”(C, D, E) respectively, as there was a regeneration effect in liver tissue of " $\mathrm{G} 3$ " and G4compared with "G2" which showing mild portal tract changes with moderately dilated and congested hepatoportal blood vessel and (Lesion score ++). Moreover "G5", showing very regenerative effect compared with "G2", by showing healthy hepatic parenchyma, note the normal hepatic cord with normal blood sinusoids, (H\&E X). 
Table 3. Effect of Fresh Purslane on liver and adipose tissue weights as well as serum lipid parameters includes cholesterol ( $\mathrm{CH}$ ), triglyceride (TG), high-density lipoprotein (HDL) and low-density lipoproteins (LDL).

\begin{tabular}{ccccccc}
\hline $\begin{array}{c}\text { Groups/ } \\
\text { Parameters }\end{array}$ & $\begin{array}{c}\text { T.adipose wt. } \\
\mathbf{( g m})\end{array}$ & Liver wt. $(\mathbf{g m})$ & CH. $(\mathbf{m g} / \mathbf{d l})$ & TG. $(\mathbf{m g} / \mathbf{d l})$ & HDL (mg/dl) & LDL (mg/dl) \\
\hline G1 & $8.13 \pm 0.09$ & $4.61 \pm 0.29$ & $78.3 \pm 2.11$ & $128 \pm 1.6$ & $39 \pm 0.83$ & $13.4 \pm 0.9$ \\
G2 & $19.43 \pm 1.07^{*}$ & $7.5 \pm 0.54^{*}$ & $93.42 \pm 4.3^{*}$ & $138 \pm 2.8^{*}$ & $31.4 \pm 1.2^{\#}$ & $34.42 \pm 2.2^{*}$ \\
G3 & $11.43 \pm 1.43^{*}$ & $6.69 \pm 0.33^{*}$ & $93 \pm 1.85$ & $132 \pm 1.7^{*}$ & $34.6 \pm 1.8^{*}$ & $32 \pm 1.5^{*}$ \\
G4 & $10.71 \pm 1.57^{*}$ & $6.59 \pm 0.38^{*}$ & $90.57 \pm 1.2$ & $130.3 \pm 1.6^{*}$ & $38.3 \pm 1.7^{*}$ & $26.2 \pm 1.2^{*}$ \\
G5 & $8.71 \pm 1.15^{*}$ & $5.0 \pm 0.31^{*}$ & $87 \pm 1.85^{*}$ & $129.7 \pm 1.3^{*}$ & $38.42 \pm 0.73^{*}$ & $22.6 \pm 0.8^{*}$ \\
\hline
\end{tabular}

Numerical data were expressed as mean \pm SD. High fat diet (HFD)group (G2), in which, 20 gm butter was added to 80 gm control diet for 28 weeks) is compared with normal control group (G1) (\#), Purslane groups (G3, G4, G5) compared with (HFD) group (G2) $\left(^{*}\right)$. P value $<0.05$ considered significant.

Table 4. Effect of fresh purslane on liver functions test in all groups.

\begin{tabular}{cccccc}
\hline $\begin{array}{c}\text { Groups/ } \\
\text { Parameters }\end{array}$ & T. protein(mg/dl) & Albumin(mg/dl) & AST(U/L) & ALT(U/L) & ALP(U/l) \\
\hline G1 & $7.4 \pm 0.07$ & $3.8 \pm 0.14$ & $18 \pm 0.75$ & $19.4 \pm 0.49$ & $60.3 \pm 1.2$ \\
G2 & $6.4 \pm 0.75^{*}$ & $3.3 \pm 0.13^{*}$ & $24.4 \pm 0.5^{*}$ & $25.14 \pm 0.6^{\#}$ & $69 \pm 0.75^{\#}$ \\
G3 & $6.9 \pm 0.1^{*}$ & $3.65 \pm 0.07^{*}$ & $20.8 \pm 0.8^{*}$ & $21.8 \pm 0.83^{*}$ & $65.8 \pm 1.1^{*}$ \\
G4 & $7.02 \pm 0.11^{*}$ & $3.62 \pm 0.069^{*}$ & $20 \pm 0.7^{*}$ & $22.7 \pm 0.7^{*}$ & $66.8 \pm 0.9^{*}$ \\
G5 & $7.4 \pm 0.11^{*}$ & $3.62 \pm 0.06^{*}$ & $20.3 \pm 0.6^{*}$ & $21.4 \pm 0.5^{*}$ & $63.1 \pm 0.8^{*}$ \\
\hline
\end{tabular}

Numerical data were expressed as mean \pm SD. High fat diet (HFD) group (G2) is compared with normal control group (G1) (\#), Putslane groups G3, $\mathrm{G} 4, \mathrm{G} 5)$ compared with High fat diet (HFD) group $(\mathrm{G} 2)\left({ }^{*}\right)$. P value $<0.05$ considered significant.

\section{The level of $\mathrm{T} 3$ on all studied groups}

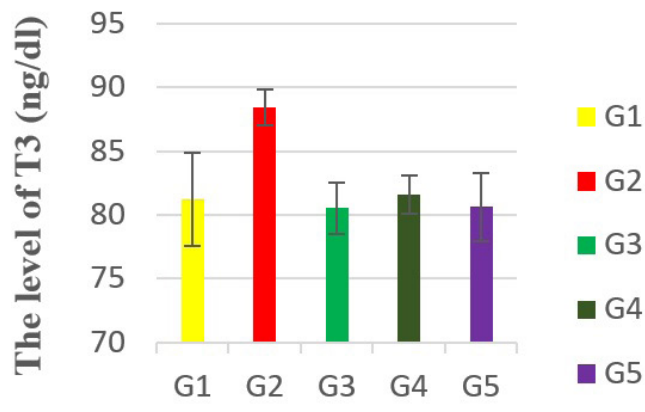

A
Studied groups

\section{The level of T4 on all studied groups}

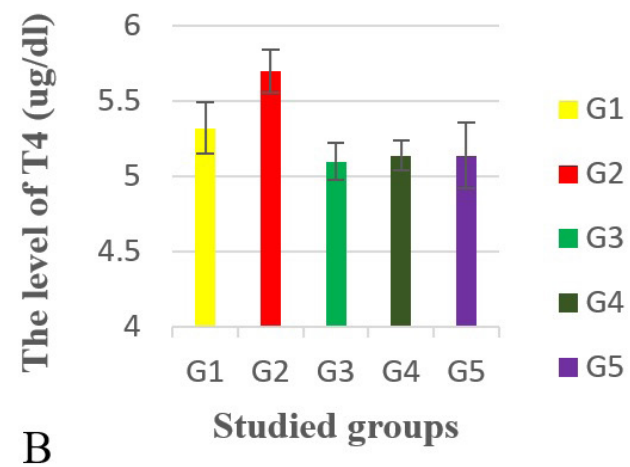

Figure 3. Showing the effect of high fat diet and fresh purslane on thyroid hormones as, T3 in (A) and T4 in (B).

\section{Discussion}

In the present study, we investigated the hypolipidemic effects of dietary supplementation of fresh purslane in different amounts of its on a high-fat diet (HFD) in rats for 8 weeks, with different doses (25\%, 50\%, and $75 \%$ ) via molecular, clinical as well as histological studies. The current study investigated the effect of fresh purslane on the regulation of gene expression of both cholesterol 7a-hydroxylase (CYP7A1) a limiting enzyme in bile acid biosynthesis from cholesterol, as well as the hepatic low-density lipoprotein receptor (LDLR). The current study showed that there were highly significant increases in the mRNA level of $L d l r$ in fresh purslane groups compared with HFD group" G2", overcome the highest level was in "G5". Meanwhile, it was an absence in the normal control group. Ldlr on cell surfaces plays a major role in the uptake of circulating LDL-C into cells (Goldstein and Brown, 2009). In addition, increased Ldlr expression in the liver is negatively correlated with lower circulating LDL-C resulting from enhanced uptake and clearance of LDL-C (Reena et al., 2011). Fresh purslane in the lipid control group also showed significantly higher expression of Cyp7a1 mRNA than was observed in the normal group. Cyp7a1 is the first and rate-limiting enzyme involved in the biosynthetic pathway that converts secreted cholesterol into bile acids (Chiang, 2009). Bile acid synthesis plays a major 
role in the hepatic regulation of cholesterol homeostasis as well as in the catabolism of cholesterol (Hebanowska, 2011). Li et al. (2010), revealed that transgenic overexpression of Cyp7a1 in the liver induced resistance to high-fat diet-induced obesity and decreased inflammation in mice. Moreover, the constitutive transgenic expression of Cyp7a1 in C57BL/6 mice prevented diet-induced hypercholesterolemia and blocked the development of atherosclerosis and gallstones (Miyake et al., 2002).

In addition, there are significant increases in levels of total cholesterol, triglycerides, LDL-C and accompanied by a low level of HDL-C levels in "G2" as shown in Table 2 than in the control group. This result has been confirmed by the previous study of Liu et al. (2015). Our findings agreed with the previous reported showing that, butter produced a significant rise in serum total cholesterol (TC) and increased serum TG, LDL-C, and decreased HDL-C (Lichtenstein et al., 1993). Meanwhile, dietary supplementation with purslane (25\%, 50\%, and $75 \%$ ) reversed the abnormal serum lipid profiles induced by dyslipidemia in HFD rats "G2", restoring healthy with the observed decreases in serum TG and TC levels, suggest that fresh purslane is beneficial for improving hyperlipidemia and hypercholesterolemia caused by HFD diet. This hypolipidemic effect of fresh purslane might be due to its contents of polyphenolics, flavonoids, alkaloids, crude fiber which have been documented as a hypolipidemic agent (ElNewary 2016). This result was coinciding with the previous study of Huang et al.(2011), who reported that purslane could significantly reduce serum total cholesterol (TC), triglyceride (TG) and low-density lipoprotein (LDL-C) content while an increased level of HDL-C was cleared (Abdalla Junior, 2010).

Moreover, there is a highly significant increase in liver weight in the HFD group compared to the control group. This increase may be due to the accumulation of cholesterol and triglyceride in the liver (Liang et al., 2014). That results from an imbalance among hepatic lipid intake, synthesis, degradation, and secretion (Tessari et al., 2009). Intake fresh purslane (25\%, $50 \%$, and $75 \%$ ) showed a significantly decreases in liver weight and lowered masses of the total adipose tissues. Cousin et al.
(1999), suggest that supplementation with purslane can prevent fat accumulation and benefit to treat obesity increased adipose tissue mass, particularly the amount of visceral fat, which is associated with an increased risk of chronic diseases, and many factors secreted by preadipocytes. This result revealed that elevation of the concentration of serum transaminase enzymes has been considered a biomarker of liver injury and damage of hepatocellular carcinoma. Huang et al. (2012) agree with the recent study of Jiang et al. (2018) the elevated levels of ALT, AST, and ALP in the HFD group were significantly lowered through supplementation of purslane diets with (50\%) and 75\%. The decreased activity of the liver enzymes, ALT, AST and ALP in the purslane treated groups, indicates its protective role against HFD-induced liver injury. The decreased activity of the liver enzymes, ALT, AST, and ALP in purslane treated group may be due to phytonutrients present in purslane including (omega3, polyunsaturated fatty acid, flavonoids) that have antioxidants effects against oxidative stress, indicates its protective role versus liver damage (Dkhil et al., 2011). The results also, demonstrated that highfat diet intake increases serum $\mathrm{T}_{3}$ and $\mathrm{T}_{4}$ level, this result was a coincidence with a previous study of Pearce (2012) and Reinehr (2011) they reported that obesity is associated with slightly increased thyroxine $\mathrm{T}_{4}$ and triiodothyronine $\mathrm{T}_{3}$ in obese individuals. The increase in thyroid hormone concentrations could point to hormone resistance, similar to insulin resistance in obesity (Srinivasan et al., 1999). Administration of fresh purslane (25\%,50\% and 75\%) decreases the elevation level of $\mathrm{T}_{3}$ and $\mathrm{T}_{4}$ hormones. Our result agreement with (EI-Serwy and Abd EI-Hameid, 2012) who reported the administration of purslane decrease the level of $\mathrm{T}_{3}$ and $\mathrm{T}_{4}$ hormone in obese rat induced by the high-fat diet.

The above results are confirmed by a histological study that showed changes in the photography of liver tissue, marked portal tract changes, note the dilated and congested hepatoportal blood vessel (arrowhead) and fibrous connective tissue proliferation (arrow) and (Lesion score +++$)$ as shown in Figure 4 (B). Administration of purslane $(25 \%, 50 \%)$ showing mild portal tract changes with
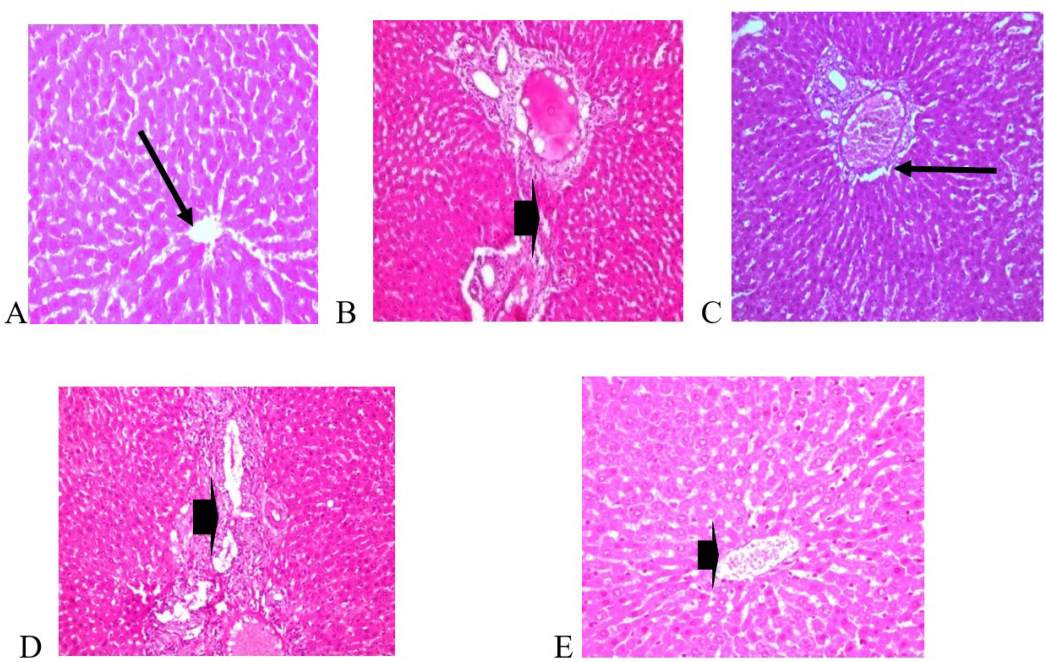

$\mathrm{E}$

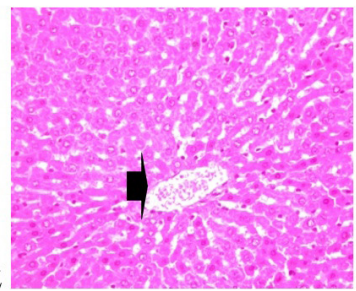

Figure 4. Showing effect of high fat diet group (B) compared with normal group (A), and the regenerative effect of fresh purslane groups (C, D and $\mathrm{E}$ ) in liver tissues of current studied groups. 
moderately dilated and congested hepatoportal blood vessel and (Lesion score ++). The dosage of fresh purslane $75 \%$ is the most effective dosage for reducing liver tissue fibrosis demonstrated a high degree of recovery and revealed almost normal hepatic lobules, healthy hepatic parenchyma, note the normal hepatic cord with normal blood sinusoids.

\section{Conclusion}

From the results of the current study, it could be concluded that purslane, has anti-obesity potential and may be useful for the treatment of obesity. Overcome, purslane administration not only has a significant decrease of serum TC, TG, and LDLC levels, but also reduces the serum AST, ALT, and ALP. Overall, the increase in hepatic CYP7A1 and JDLR gene expression may be a mechanism that partially accounts for the hypolipidemic effect of purslane.

\section{References}

ABDALLA JUNIOR, H.M., 2010. Purslane extract effects on obesityinduced diabetic rats fed a high-fat diet. Malaysian Journal of Nutrition, vol. 16, no. 3, pp. 419-429. PMid:22691995.

ANSTEE, M.Q. and GOLDIN, D.R., 2006. Mouse models in nonalcoholic fatty liver disease and steatohepatitis research. International Journal of Experimental Pathology, vol. 87, no. 1, pp. 1-16. http://dx.doi.org/10.1111/j.0959-9673.2006.00465.x. PMid: 16436109.

BOSI, G., GUARRERA, P.M., RINALDI, R. and BANDINI MAZZANTI, M., 2009. Ethnobotany of purslane (Portulaca oleracea L.) in Italy and morfo-biometric analyses of seeds from archaeological sites of Emilia Romagna (Northern Italy). In: J.P. MOREL and A.M. MERCURI, eds. Plants and culture: seeds of the cultural heritage of Europe. Bari: Edipuglia, pp. 129-139.

CHIANG, J.Y., 2009. Bile acids: regulation of synthesis. Journal of Lipid Research, vol. 50, no. 10, pp. 1955-1966. http://dx.doi. org/10.1194/jlr.R900010-JLR200. PMid:19346330.

COUSIN, B., MUNOZ, O., ANDRE, M., FONTANILLES, A.M., DANI, C., COUSIN, J.L., LAHARRAGUE, P., CASTEILLA, L. and PÉNICAUD, L., 1999. A role for preadipocytes as macrophage-like cells. The FASEB Journal, vol. 13, no. 2, pp. 305-312. http://dx.doi. org/10.1096/fasebj.13.2.305. PMid:9973318.

CULLING, C.F.A., 1983. Handbook of histopathological and histochemical technique. 3rd ed. London: Butterworths; 214.

DKHIL, M.A., MONIEM, A.E.A., AL-QURAISHY, S. and SALEH, R.A., 2011. Antioxidant effect of purslane (Portulaca oleracea) and its mechanism of action. Journal of Medicinal Plants Research, vol. 5, no. 9, pp. 1589-1593.

EI-SERWY, E. and ABD EI-HAMEID, M., 2012. Influence of sage (Salvia officinalis L.) and Purslane (Portulaca oleracea L.) on weight reduction and some biochemical parameters in rats suffering from obesity. Egyptian Journal of Nutrition and Health, vol. 7, no. 1, pp. 1-16. http://dx.doi.org/10.21608/ejnh.2012.4807.

ELDEIGHDYE, S.M., ABDEL-KHALEK, L.G., TAHA, M.S., ALLAM, T.M., HASSANIAN, W.F., KESHTA, A.T. and EL FARARGY, A., 2016. Effect of Purslane (Portulaca oleracea) extraction on wound healing in diabetic albino rats. World Journal of Pharmacy and Pharmaceutical Sciences, vol. 5, no. 11, pp. 1454-1469.

EL-NEWARY, S.A., 2016. The hypolipidemic effect of Portulaca oleracea L. stem on hyperlipidemic Wister Albino rats. Annals of Agricultural Science, vol. 61, no. 1, pp. 111-124. http://dx.doi. org/10.1016/j.aoas.2016.01.002.

ENGIZ, O., BERBEROĞLU, M., SIKLAR, Z. and OÇAL, G., 2009. Risk factors for non-alcoholic fatty liver disease in obese children. Hormone Research, vol. 72, no. 1, pp. 63-64. http://dx.doi. org/10.1159/000224343. PMid:19571562.

GIRISH, C. and PRADHAN, S.C., 2012. Indian herbal medicines in the treatment of liver diseases: problems and promises. Fundamental E Clinical Pharmacology, vol. 26, no. 2, pp. 180-189. http:// dx.doi.org/10.1111/j.1472-8206.2011.01011.x. PMid:22136107.

GOLDSTEIN, J.L. and BROWN, M.S., 2009. The LDL receptor. Arteriosclerosis, Thrombosis, and Vascular Biology, vol. 29, no. 4, pp. 431-438. http://dx.doi.org/10.1161/ATVBAHA.108.179564. PMid:19299327.

HEBANOWSKA, A., 2011. Mechanisms of bile acid biosynthesis regulation: autoregulation by bile acids. Postepy Biochemii, vol. 57, no. 3, pp. 314-323. PMid:22235657.

HUANG, G.J., DENG, J.S., HUANG, S.S., SHAO, Y.Y., CHEN, C.C. and KUO, Y.H., 2012. Protective effect of antrosterol from antrodia camphorata submerged whole broth against carbon tetrachloride-induced acute liver injury in mice. Food Chemistry, vol. 132, no. 2, pp. 709-716. http://dx.doi.org/10.1016/j. foodchem.2011.11.004.

HUANG, X.X., ZHANG, Y.W., ZHANG, R.C., LI, Q.S. and SONG, C.M., 2011. Protective effect of Purslane on hyperlipidemic rat livers. Journal of Jilin Medical College, vol. 32, no. 1, pp. 1673-2995.

JIANG, Y., FU, C., LIU, G., GUO, J. and SU, Z., 2018. Cholesterol-lowering effects and potential mechanisms of chitooligosaccharide capsules in hyperlipidemic rats. Food E Nutrition Research, vol. 62, pp. 62. http://dx.doi.org/10.29219/fnr.v62.1446. PMid:29922118.

LARSEN, P.R., 1972. Direct immunoassay of triiodothyronine in human serum. The Journal of Clinical Investigation, vol. 51, no. 8, pp. 1939-1949. http://dx.doi.org/10.1172/JCI107000. PMid:4626581.

LEVESQUE, R., 2005. SPSS programming and data management: $a$ guide for SPSS and SAS users. Chicago: SPSS.

LI, T., OWSLEY, E., MATOZEL, M., HSU, P., NOVAK, C.M. and CHIANG, J.Y., 2010. Transgenic expression of cholesterol $7 \alpha$-hydroxylase in the liver prevents high-fat diet-induced obesity and insulin resistance in mice. Hepatology, vol. 52, no. 2, pp.678-690. http:// dx.doi.org/10.1002/hep.23721. PMid:20623580.

LIANG, W., MENKE, A.L., DRIESSEN, A., KOEK, G.H., LINDEMAN, J.H., STOOP, R., HAVEKES, L.M., KLEEMANN, R. and VAN DEN HOEK, A.M., 2014. Establishment of a general NAFLD scoring system for rodent models and comparison to human liver pathology. PLoS One, vol. 9, no. 12, pp. e115922. http://dx.doi.org/10.1371/ journal.pone.0115922. PMid:25535951.

LICHTENSTEIN, A.H., AUSMAN, L.M., CARRASCO, W., JENNER, J.L., ORDOVAS, J.M. and SCHAEFER, E.J., 1993. Hydrogenation impairs the hypolipidemic effect of corn oil in humans: hydrogenation, trans- fatty acids, and plasma lipids. Arteriosclerosis and Thrombosis: a Journal of Vascular Biology, vol. 13, no. 2, pp. 154161. http://dx.doi.org/10.1161/01.ATV.13.2.154. PMid:8427852.

LIU, L., LIAO, P., WANG, B., FANG, X., LI, W. and GUAN, S., 2015. Baicalin inhibits the expression of monocyte chemoattractant protein-1 and interleukin- 6 in the kidneys of apolipoprotein E-knockout mice fed a high cholesterol diet. Molecular Medicine Reports, vol. 11, no. 5, pp. 3976-3980. http://dx.doi.org/10.3892/ mmr.2015.3186. PMid:25586053.

MIYAKE, J.H., DUONG-POLK, X.T., TAYLOR, J.M., DU, E.Z., CASTELLANI, L.W., LUSIS, A.J. and DAVIS, R.A., 2002. Transgenic expression of cholesterol-7- $\alpha$-hydroxylase prevents atherosclerosis 
in C57BL/6J mice. Arteriosclerosis, Thrombosis, and Vascular Biology, vol. 22, no. 1, pp. 121-126. http://dx.doi.org/10.1161/ hq0102.102588. PMid:11788471.

OLIVEIRA, I., COELHO, V., BALTASAR, R., PEREIRA, J.A. and BAPTISTA, P., 2009. Scavenging capacity of strawberry tree (Arbutus unedo L.) leaves on free radicals. Food and Chemical Toxicology, vol. 47, no. 7, pp. 1507-1511. http://dx.doi.org/10.1016/j.fct.2009.03.042. PMid:19351553.

PEARCE, E.N., 2012. Thyroid hormone and obesity. Current Opinion in Endocrinology, Diabetes, and Obesity, vol. 19, no. 5, pp. 408-413. http://dx.doi.org/10.1097/MED.0b013e328355cd6c. PMid:22931855.

PEREIRA, C.A., PEREIRA, L.L.S. and CORRÊA, A.D., 2010. Hoodia gordonii in the treatment of obesity: a review. Journal of Medicinal Plants Research, vol. 4, no. 22, pp. 2305-2312.

REENA, M.B., GOWDA, L.R. and LOKESH, B.R., 2011. Enhanced hypocholesterolemic effects of interesterified oils are mediated by upregulating LDL receptor and cholesterol 7 - $\alpha$-hydroxylase gene expression in rats. The Journal of Nutrition, vol. 141, no. 1, pp. 24-30. http://dx.doi.org/10.3945/jn.110.127027. PMid:21106933.

REINEHR, T., 2011. Thyroid function in the nutritionally obese child and adolescent. Current Opinion in Pediatrics, vol. 23, no. 4, pp. 415-420. http://dx.doi.org/10.1097/MOP.0b013e328344c393. PMid:21430532.

ROHIT, K., FELDSTEIN, A.E. and KIBRY, M., 2010. High-fructose, medium chain trans-fat diet induces liver fibrosis and elevates plasma coenzyme Q9 in a novel murine model of obesity and non-alcoholic steatohepatitis. The Hematology Journal, no. 52, pp. 934-944.

SHANKER, N. and DEBNATH, S., 2016. Hypolipidemic effect of Purslane (Portulaca oleracea L.) in rats fed on high cholesterol diet.Journal of Nutrition \& Food Sciences, vol. 6, no. 06, pp. 558. http://dx.doi.org/10.4172/2155-9600.1000557.

SHANKER, N. and DEBNATH, S., 2018. Hypolipidemic effect of Purslane (Portulaca oleracea L.) in rats fed on high cholesterol diet. Nutrition E' Food Science, vol. 6, no. 6, pp. 1-8.
SHARMA, N. and PATNI, V., 2012. Grewia tenax (Frosk.) Fiori. a traditional medicinal plant with enormous economic prospectives. Asian Journal of Pharmaceutical and Clinical Research, vol. 5, no. 3, pp. 28-32.

SRINIVASAN, S.R., MYERS, L. and BERENSON, G.S., 1999. Temporal association between obesity and hyperinsulinemia in children, adolescents, and young adults: the Bogalusa Heart Study. Metabolism: Clinical and Experimental, vol. 48, no. 7, pp. 928-934. http://dx.doi.org/10.1016/S0026-0495(99)90231-7. PMid:10421238.

TESSARI, P., CORACINA, A., COSMA, A. and TIENGO, A., 2009. Hepatic lipid metabolism and non-alcoholic fatty liver disease. Nutrition, Metabolism, and Cardiovascular Diseases, vol. 19, no. 4, pp. 291-302. http://dx.doi.org/10.1016/j.numecd.2008.12.015. PMid:19359149.

TIETZ, N.W., 1995. Clinical guide to laboratory tests. 3rd ed. Philadelphia: W.B. Saunders, 596 p.

UDDIN, M.K., JURAIMI, A.S., HOSSAIN, M.S., NAHAR, M.A., ALI, M.E. and RAHMAN, M.M., 2014. Purslane weed (Portulaca oleracea): a prospective plant source of nutrition, omega-3 fatty acid, and antioxidant attributes. The Scientific World Journal, vol. 2014, pp. 951019. PMid:24683365.

WOODS, S.C., SEELEY, R.J., RUSHING, P.A., D’ALESSIO, D. and TSO, P., 2003. A controlled high-fat diet induces an obese syndrome in rats. The Journal of Nutrition, vol. 133, no. 4, pp. 1081-1087. http://dx.doi.org/10.1093/jn/133.4.1081. PMid:12672923.

XU, X., YU, L. and CHEN, G., 2006. Determination of flavonoids in Portulaca oleracea L. by capillary electrophoresis with electrochemical detection. Journal of Pharmaceutical and Biomedical Analysis, vol. 41, no. 2, pp. 493-499. http://dx.doi. org/10.1016/j.jpba.2006.01.013. PMid:16516429.

ZHOU, Y.X., XIN, H.L., RAHMAN, K., WANG, S.J., PENG, C. and ZHANG, H., 2015. Portulaca oleracea L.: a review of phytochemistry and pharmacological effects. BioMed Research International, vol. 2015, pp. 925631. http://dx.doi.org/10.1155/2015/925631. PMid:25692148. 